\title{
The Origins and Implications of Language Effects in Multilingual Surveys: A MIMIC Approach with Application to Latino Political Attitudes
}

\author{
Efrén O. Pérez \\ Department of Political Science, Vanderbilt University, PMB 505, 230 Appleton Place, Nashville, TN 37203 \\ e-mail: efren.o.perez@vanderbilt.edu
}

\begin{abstract}
The study of Latino public opinion has renewed interest in the relationship between language and survey response. However, extant research generally relies on statistical methods that cannot distinguish between two related yet distinct types of language effects in Latino surveys: (1) differences in attitude and (2) differences in measures of attitude. The former reflects varied levels of a latent attitude between English and Spanish interviewees. The latter—formally known as Differential Item Functioning (DIF)—refers to linguistic differences in the interpretation of survey items, which lead Latino respondents to misreport their level of attitude. This paper proposes Multiple Indicators Multiple Causes models to decouple these two types of language effects. Using this modeling framework, I examine language differences in measures of subjective and factual political attitudes from the Latino National Survey (2006). I find that the language of interview systematically colors Latinos' interpretation of survey items, even after controlling for measurement error and individual differences in the latent variable being assessed. I then show through an applied analysis how ignoring language DIF can yield misleading inferences about hypothesized relationships between variables. Together, these findings highlight a need for greater theoretical work on the psychological origins of language effects in multilingual political surveys.
\end{abstract}

\section{Introduction}

The growth of Latinos in the United States has stimulated vigorous efforts to measure and diagnose their political attitudes (Uhlaner and Garcia 2002; Garcia 2003). Yet increased polling among Latinos has also raised questions about the relationship between the language of interview and the meaning of survey items (Lee 2001; Perreira et al. 2005; Diaz-Morales et al. 2006; Pérez 2009). To this end, some scholarship has focused on differences in levels of attitude by language of interview, finding English and Spanish interviewees score differently on survey questions (Welch et al. 1973; Lee 2001). Other research, in contrast, has studied the validity of Latino survey items and discovered that some of these are incomparable across language of interview (Benet-Martinez and John 1998; Diaz-Morales et al. 2006; Pérez 2009). Despite differences in methodological approach, both types of research claim language shapes the meaning of political attitudes for Latinos. Ironically, however, this inference is weakened by each methodology's inability to disentangle language differences in attitude from language differences in measures of attitude. This paper proposes a statistical framework, known as Multiple Indicators Multiple Causes (MIMIC), which differentiates between these two influences and yields clear implications for the design and use of Latino survey items. ${ }^{1}$

Author's note: I would like to thank John Geer and Cindy Kam for their thoughtful comments and advice on this paper. I am especially grateful for Katharine Donato's incisive feedback and gentle encouragement on this project. Any remaining errors are my responsibility alone. Replication materials are available at http://hdl.handle.net/1902.1/16235.

${ }^{1}$ This paper centers on the case of Latino political attitudes, but the general argument and methodology can be applied to other cases, such as Asian Americans. I focus on Latinos because the data I employ 1) contain multiitem batteries to measure several latent political constructs of a subjective and factual variety and 2) yield an incredibly large number of cases with rich variation in key covariates (e.g., language, national origin, generation). These features ensure enough statistical power to confirm or disconfirm the main measurement hypotheses being tested by MIMIC models. This endeavor, however, could not proceed in the same manner if I utilized a data set such as the Pilot National Asian American Political Survey (PNAAPS), 2000-2001, for the reasons described above. 


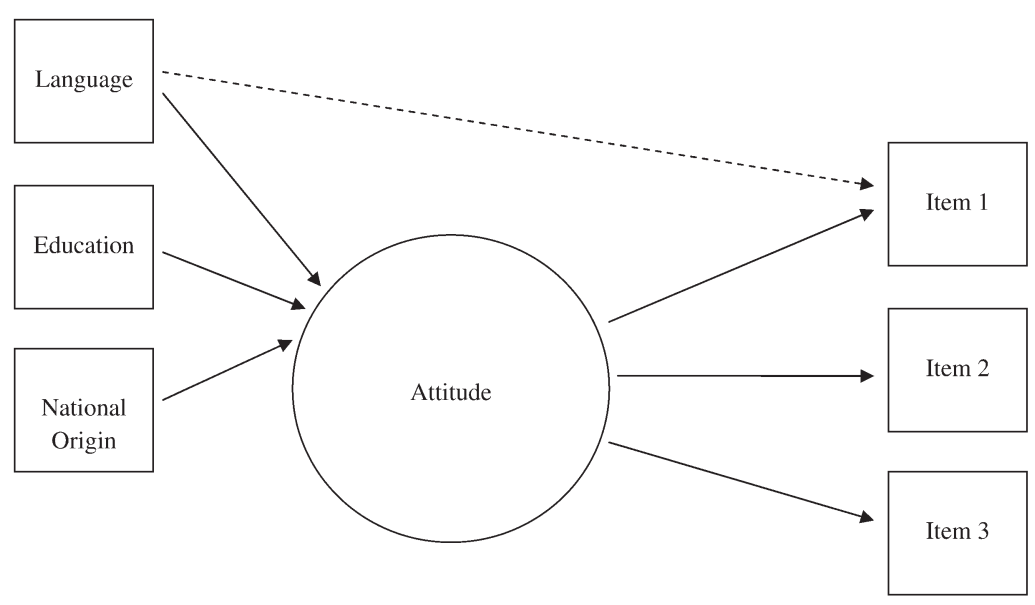

Notes: The bolded arrows pointing to Attitude reflect the influence of each covariate on the underlying construct. Those paths capture individual differences in the latent attitude under measurement. The bolded arrows pointing to Items 1 through 3 reflect the influence of Attitude on the measures of the latent construct. Those paths represent the loadings in the factor analytic component of the MIMIC model. The dashed line from Language to Item 1 reflects the hypothesized Differential Item Functioning of that observed indicator.

Fig. 1 Visualizing the basic components of a MIMIC model.

Though previous research has found that English and Spanish interviewees often display substantive differences of political opinion (Welch et al. 1973; Kirkman-Liff and Mondragón 1991; Lee 2001), this evidence has two plausible interpretations. On the one hand, it can reflect-as current research suggests-real language differences in the latent variables under study. On the other hand, it can reflect Differential Item Functioning (DIF), that is, differences in how questions perform among English and Spanish interviewees (Hambleton et al. 1991; Brown 2007). If DIF is present, any observed language gaps in survey questions reflect a systematic over- or under-reporting of true individual differences in the underlying attitude.

To address this concern, some analysts have examined the linguistic validity of Latino survey items and found that subtle differences in translated questions lead English and Spanish interviewees to report varied levels of attitude (e.g., Pérez 2009). Yet this evidence also has two plausible interpretations. It can reflectas extant work suggests-DIF. Or, it can signal individual differences-besides language-in the underlying attitude. Indeed, since this work uses methodologies that can generally handle only one individual difference at a time (e.g., Multi-Group Confirmatory Factor Analysis [MGCFA]), it cannot rule out these additional sources of attitudinal differences. This is crucial because Latinos display enormous social and political diversity (Garcia Bedolla 2003, 2009). Thus, by overlooking other individual differences in a latent attitude (e.g., generational status), scholars risk misattributing weak item validity to language rather than these omitted considerations.

This paper addresses these blind spots in previous work by proposing the use of MIMIC models, which distinguish DIF from heterogeneity in the attitude being measured (e.g., Jöreskog and Goldberger 1975;

Table 1 Confirmatory factor analysis: perceptions of Americanism

Perceptions of Americanism

Born in the U.S.

$0.763(0.025)$

Speak English

$0.466(0.026)$

Being White

$0.582(0.022)$

Being Christian

0.357 (0.019)

CFI

0.993

TLI

0.958

RMSEA

0.043

Note. Weighted least squares estimates. $N=7688$. The variance of each factor is fixed to 1.0 to identify the model. Cells contain standardized factor loadings, with SEs in parentheses. The factor has units of one SD. Item loadings are all significant at the $1 \%$ level or better. 
Table 2 Confirmatory factor analysis: political knowledge

\begin{tabular}{lc}
\hline & Political knowledge \\
\hline Majority party & $0.790(0.021)$ \\
Conservative party & $0.706(0.020)$ \\
2004 Election & $0.594(0.019)$ \\
CFI & 1.000 \\
TLI & 1.000 \\
RMSEA & 0.000 \\
\hline
\end{tabular}

Note. Weighted least squares estimates. $N=7688$. The variance of each factor is fixed to 1.0 to identify the model. Cells contain standardized factor loadings, with SEs in parentheses. The factor has units of one SD. Item loadings are all significant at the $1 \%$ level or better

Muthén 1989; Gallo et al. 1994; Mast and Lichtenberg 2000; Brown 2007; Proitsi et al. 2011). ${ }^{2}$ MIMIC models are regressions where the criterion is a latent variable measured with multiple items, and the predictors are individual-level difference variables. This configuration means scholars with a working knowledge of linear regression can make use and sense of the output yielded by MIMIC models. In MIMIC models, scholars first validate items measuring a latent attitude through a factor analysis, itself a form of regression (Bollen 1989; Brown 2007). Scholars then assess whether a covariate, like the language of interview, affects these items after individual differences in the latent variable are controlled. If it does, the evidence suggests DIF, which means that at any value of a latent attitude, English (Spanish) interviewees will score differently on an item because it means something different to members of each language group. ${ }^{3}$

Using the Latino National Survey (LNS) (2006), I estimate four MIMIC models with measures of political knowledge, perceptions of Americanism, Latino attachment, and perceptions of intergroup competition. These constructs allow me to assess whether language affects the measurement of subjective (e.g., Americanism perceptions) and factual (e.g., political knowledge) attitudes. I find that English and Spanish interviewees generally register mean differences on survey items, even after measurement error and individual differences in a latent attitude are controlled - a pattern reflecting linguistic DIF. I then illustrate the consequences of this DIF through a regression analysis involving the affected items. I show assuming the absence of DIF when it in fact exists can lead one to incorrectly reject one's null hypothesis. Combined, this evidence calls for greater research on the political psychology of survey language effects.

\section{Language Effects in Latino Surveys}

Scholarship broadly documents the influence of language on Latinos' survey responses (Welch et al. 1973; Kirkman-Liff and Mondragón 1991; Benet-Martínez and John 1998; Lee 2001; Perreira et al. 2005; DiazMorales et al. 2006; Lee et al. 2008; Pérez 2009). Yet research has not determined whether linguistic differences in attitude are true differences between language groups or artifacts of DIF. Consider Latino levels of political knowledge (Delli Carpini and Keeter 1996). Abrajano (2010) found that English interviewees display substantially more political knowledge than Spanish interviewees (see also Abrajano and Alvarez 2010). One interpretation is that linguistic DIF is responsible for these differences in political knowledge. Here, English interviewees know more about politics, not because they are better informed but because knowledge items are easier for them to answer. For instance, translated items might adhere more closely to the cultural norms of English speakers, thereby facilitating English interviewees' answers to these questions (Marín and Marín 1991).

Yet another interpretation is that knowledge gaps are produced by Latino heterogeneity. Here, knowledge gaps emerge, not from linguistically biased items but from Latino variation in national origin, citizenship status, education, generational status, and access to political information (Garcia Bedolla 2005; Branton 2007; Abrajano 2010; Abrajano and Alvarez 2010). For example, language gaps in knowledge might be

\footnotetext{
${ }^{2}$ The detection of these biases can be exploratory (i.e., data driven) or confirmatory (i.e., hypothesis driven) (Brown 2007). My use of MIMIC models is inherently confirmatory since I expect language to play a role in producing DIF.

${ }^{3}$ This difference in interpretation is essentially a form of bias, akin to the way that race may affect the way items on standardized tests are construed (e.g., Hambleton et al. 1991).
} 
Table 3 Confirmatory factor analysis: Latino attachment

\begin{tabular}{lc}
\hline & Latino attachment \\
\hline Ethnic_economic commonality & $0.637(0.016)$ \\
Ethnic_political commonality & $0.616(0.016)$ \\
Ethnic_linked fate & $0.475(0.015)$ \\
Individual_political commonality & $0.554(0.016)$ \\
Individual_economic commonality & $0.606(0.016)$ \\
Individual_linked fate & $0.470(0.015)$ \\
CFI & 0.981 \\
TLI & 0.953 \\
RMSEA & 0.072 \\
\hline
\end{tabular}

Note. Weighted least squares estimates. $N=7688$. The variance of each factor is fixed to 1.0 to identify the model. Cells contain standardized factor loadings, with SEs in parentheses. The factor has units of one SD. Item loadings are all significant at the $1 \%$ level or better.

explained by Latino differences in education since greater education increases knowledge about politics (Delli Carpini and Keeter 1996; Abrajano and Alvarez 2010). This scenario implies that language DIF will be absent if social, educational, and political variation among Latino respondents is statistically controlled.

Although the above scenarios are both theoretically plausible, methodological approaches often privilege one explanation over the other. For instance, scholars using regression analysis or differencein-means tests have discovered robust language differences in Latino attitudes (Welch et al. 1973; Kirkman-Liff and Mondragón 1991; Lee 2001; Lee et al. 2008). These differences often persist despite statistical controls for, inter alia, education, national origin, and citizenship status. But, to confidently infer that these differences stem from language, one must assume that survey questions have equivalent meaning across language. Formally, this means that survey items are invariant, that is, they capture the same attitude to the same degree across language groups (Byrne and Watkins 2003; Brown 2007). Yet comparative survey research has found that linguistic invariance often does not hold for survey items (Davidov 2009; Elkins and Sides 2010).

As a result, scholars have examined the validity of items translated from English to Spanish (BenetMartínez and John 1998; Diaz-Morales et al. 2006). For example, using MGCFA, Pérez (2009) finds several item loadings and thresholds in bilingual items that produce meaningful differences across language (i.e., noninvariance). Yet this model can handle only one individual difference at a time (e.g., language of interview) (Bollen 1989; Brown 2007). ${ }^{4}$ Thus, it cannot rule out that weak item validity arises, not from language bias but from omitted differences among Latinos (e.g., education) (de la Garza et al.

Table 4 Confirmatory factor analysis: perceived intergroup competition

\begin{tabular}{lcc}
\hline & Black competition & Latino competition \\
\hline Government jobs & $0.864(0.007)$ & $0.884(0.006)$ \\
Quality schools & $0.820(0.008)$ & $0.843(0.007)$ \\
Jobs & $0.760(0.009)$ & $0.764(0.009)$ \\
Elected representatives & $0.742(0.009)$ & $0.792(0.007)$ \\
Inter-factor correlation $\mathbf{. 5 9}$ & & \\
CFI & 0.988 & \\
TLI & 0.982 & \\
RMSEA & 0.058 & \\
\hline
\end{tabular}

Note. Weighted least squares estimates. $N=7688$. The variance of each factor is fixed to 1.0 to identify the model. Cells contain standardized factor loadings, with SEs in parentheses. The factor has units of one SD. Item loadings and inter-factor correlations are all significant at the $1 \%$ level or better.

\footnotetext{
${ }^{4}$ One could reconfigure data into groups that vary the language of interview while holding constant other covariates, as in Pérez's (2009) comparison between high-education English and high-education Spanish interviewees. This approach requires a large number of cases, which is difficult to sustain with many available Latino surveys.
} 
Table 5 Influence of covariates on latent perceptions of Americanism

\begin{tabular}{|c|c|}
\hline & Full model \\
\hline Language (English) & $-0.284 *(0.050)$ \\
\hline Switch & $-0.003(0.046)$ \\
\hline Cuban & $0.186 *(0.085)$ \\
\hline Puerto Rican & $-0.010(0.062)$ \\
\hline Dominican & $0.174(0.094)$ \\
\hline Salvadoran & $0.448 *(0.074)$ \\
\hline Second generation & $0.255^{*}(0.064)$ \\
\hline Third generation & $0.228 *(0.065)$ \\
\hline U.S. citizen & $-0.064(0.049)$ \\
\hline Education & $-0.082 *(0.012)$ \\
\hline Democrat & $0.237 *(0.048)$ \\
\hline Republican & $0.242 *(0.066)$ \\
\hline Independent & $0.127 *(0.057)$ \\
\hline No party & $-0.121 *(0.056)$ \\
\hline English media & $-0.049 *(0.053)$ \\
\hline Spanish media & $0.109 *(0.046)$ \\
\hline Estimated $R^{2}$ & 0.070 \\
\hline
\end{tabular}

Note. Dependent variable is latent perceptions of Americanism. Weighted least squares estimates, with SEs in parentheses. $N=7688$. $* p<.05$, two-tailed test.

1992; Garcia Bedolla 2005; Branton 2007; Abrajano and Alvarez 2010). Hence, survey items might achieve linguistic invariance if this response variability is controlled.

Below, I introduce MIMIC models as a way to disentangle the possible effects of these considerations on Latinos' survey responses. The advantage of this statistical framework is that it can simultaneously assess the linguistic validity of survey items (Benet-Martínez and John 1998; Pérez 2009) while holding constant individual differences in Latino political attitudes (Welch et al. 1973; Lee 2001). In this way, MIMIC models seize the best elements of previous research to shed new light on the relationship between Latinos, language, and survey response.

\section{Decoupling Language Effects through MIMIC Models}

I propose MIMIC models to detangle DIF from heterogeneity in Latino attitudes being measured. DIF is the degree to which equally able individuals report different levels of an attitude due to item bias. If a set of questions reliably measures an attitude, DIF indicates whether items are differentially construed by people. DIF is revealed by item mean differences between groups that remain after observed heterogeneity in the underlying attitude is statistically controlled (Bollen 1989). ${ }^{5}$ Of course, it is still possible that the groups under comparison differ on some unobserved variables. This framework therefore assumes that the groups under comparison are identical on any remaining unobservable(s). ${ }^{6}$ In the conclusion, I return to this assumption and discuss its possible solution.

The general mechanics behind MIMIC models involve the following. First, items purporting to measure an attitude are validated. If valid, those items should be robustly correlated-an indication the items are in fact tapping the same latent variable. Second, once the covariances between those items are taken into account through a factor analysis, there should be no systematic variance left to explain since the items are assumed to capture only the attitude in question — and nothing else. Third, DIF is detected when and if any remaining variation in these items can be explained by an individual-difference variable, such as the language of interview. These different model components are visually displayed in Fig. 1.

\footnotetext{
${ }^{5}$ This means any inferences regarding DIF hinge on a well-specified regression component of a MIMIC model. The quality of one's specification should be dictated by extant theory. Fortunately, in the case of Latino political attitudes, there is a general consensus about the main sources of heterogeneity in Latino opinion (e.g., de la Garza et al. 1992; Branton 2007; Abrajano and Alvarez 2010). ${ }^{6} \mathrm{I}$ thank an anonymous reviewer for pointing this out.
} 
Table 6 Influence of covariates on latent political knowledge

\begin{tabular}{|c|c|}
\hline & Full model \\
\hline Language (English) & $0.174 *(0.058)$ \\
\hline Switch & $-0.072(0.055)$ \\
\hline Cuban & $0.586 *(0.101)$ \\
\hline Puerto Rican & $-0.111(0.073)$ \\
\hline Dominican & $-0.053(0.105)$ \\
\hline Salvadoran & $0.183 *(0.093)$ \\
\hline Second generation & $0.229 *(0.075)$ \\
\hline Third generation & $0.319 *(0.075)$ \\
\hline U.S. citizen & $0.317 *(0.056)$ \\
\hline Education & $0.164 *(0.013)$ \\
\hline Democrat & $1.118 *(0.063)$ \\
\hline Republican & $1.477 *(0.082)$ \\
\hline Independent & $0.832 *(0.073)$ \\
\hline No party & $0.146 *(0.073)$ \\
\hline English media & $0.440 *(0.060)$ \\
\hline Spanish media & $-0.215^{*}(0.053)$ \\
\hline Estimated $R^{2}$ & 0.497 \\
\hline
\end{tabular}

Note. Dependent variable is latent political knowledge. Weighted least squares estimates, with SEs in parentheses. $N=7688$. $* p<.05$, two-tailed test.

Formally, a MIMIC framework (e.g., Jöreskog and Goldberger 1975; Gallo et al. 1994) involves estimating the following general model in sequential steps:

$$
y_{i}=v+\lambda \eta_{i}+k x_{i 1}+\varepsilon_{i}
$$

Here, $v$ is an intercept parameter and $\lambda$ is the factor loading relating the factor $\eta$ to indicator $y$ for individual $i$. This represents the Confirmatory Factor Analytic (CFA) component of the MIMIC model

Table 7 Influence of covariates on latent Latino attachment

\begin{tabular}{|c|c|}
\hline & Full model \\
\hline Language (English) & $-0.244 *(0.048)$ \\
\hline Switch & $0.054(0.045)$ \\
\hline Cuban & $-0.194 *(0.080)$ \\
\hline Puerto Rican & $-0.022(0.059)$ \\
\hline Dominican & $0.081(0.085)$ \\
\hline Salvadoran & $-0.019(0.069)$ \\
\hline Second generation & $0.050(0.059)$ \\
\hline Third generation & $-0.109(0.060)$ \\
\hline U.S. citizen & $0.095 *(0.045)$ \\
\hline Education & $0.025(0.010)$ \\
\hline Democrat & $0.180 *(0.046)$ \\
\hline Republican & $0.178 *(0.060)$ \\
\hline Independent & $0.007(0.053)$ \\
\hline No party & $-0.108 *(0.052)$ \\
\hline English media & $-0.281 *(0.049)$ \\
\hline Spanish media & $-0.084(0.043)$ \\
\hline Estimated $R^{2}$ & 0.050 \\
\hline
\end{tabular}

Note. Dependent variable is latent Latino attachment. Weighted least squares estimates, with SEs in parentheses. $N=7,688$. $* p<.05$, two-tailed test. 
Table 8 Influence of covariates on latent perceptions of intergroup competition

\begin{tabular}{lcc}
\hline & Black competition & Latino competition \\
\hline Language (English) & $\mathbf{0 . 0 1 6}(\mathbf{0 . 0 4 1})$ & $\mathbf{- 0 . 1 9 2 * ( \mathbf { 0 . 0 4 1 } )}$ \\
Switch & $-0.002(0.038)$ & $0.009(0.038)$ \\
Cuban & $-0.132^{*}(0.063)$ & $-.321^{*}(0.067)$ \\
Puerto Rican & $0.203^{*}(0.053)$ & $-.058(0.053)$ \\
Dominican & $0.245^{*}(0.077)$ & $0.138(0.077)$ \\
Salvadoran & $0.315^{*}(0.061)$ & $0.201 * *(0.066)$ \\
Second generation & $0.017(0.054)$ & $0.155^{*}(0.055)$ \\
Third generation & $0.061(0.054)$ & $0.150^{*}(0.053)$ \\
U.S. citizen & $0.038(0.040)$ & $0.052(0.039)$ \\
Education & $0.000(0.009)$ & $0.016(0.009)$ \\
Democrat & $0.299^{*}(0.041)$ & $0.250^{*}(0.040)$ \\
Republican & $0.290^{* *}(0.055)$ & $0.276^{*}(0.055)$ \\
Independent & $0.257^{*}(0.048)$ & $0.207 *(0.048)$ \\
No party & $0.000(0.048)$ & $-0.026(0.046)$ \\
English media & $0.053(0.044)$ & $-0.047(0.044)$ \\
Spanish media & $0.037(0.038)$ & $0.011(.037)$ \\
Estimated $R^{2}$ & 0.034 & 0.030 \\
\hline
\end{tabular}

Note. Dependent variable is latent perceptions of intergroup competition. Weighted least squares estimates, with SEs in parentheses. $N=7688$.

$* p<.05$, two-tailed test.

that is initially estimated. If the CFA produces a well-fitting measurement model, language, $x_{i 1}$, and other covariates, $x_{i 2} \ldots x_{i p}$, are related to the underlying factor via the following equation to ascertain individual differences in the underlying attitude, $\eta$ :

$$
\eta_{i}=\gamma_{1} x_{i 1}+\gamma_{2} x_{i 2} \ldots+\gamma_{p} x_{i p}+\zeta_{i}
$$

Equation (1) is then fully estimated by assessing $k$, which represents the direct effect of language on indicator $y$, while holding constant differences in the underlying attitude, $\eta$, as well as item reliability. ${ }^{7}$ Thus, $k$ yields our estimate of DIF in a particular survey item, which can be interpreted as revealing a mean

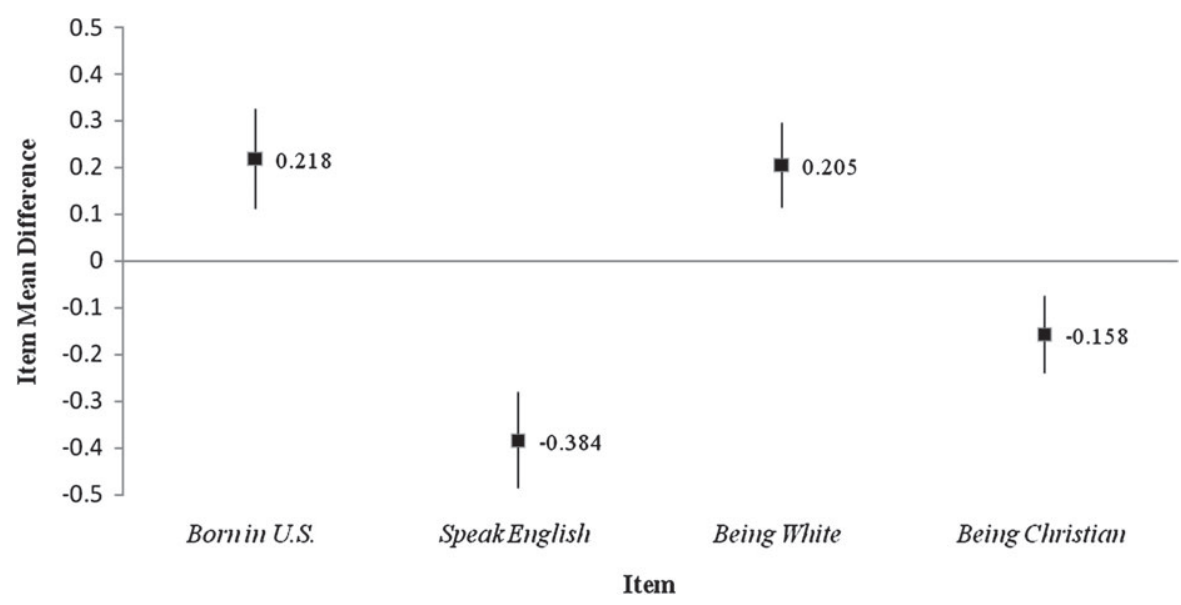

Fig. 2 Perceptions of Americanism: DIF estimates with 95\% confidence intervals.

\footnotetext{
${ }^{7}$ This general framework assumes continuous and normally distributed items are used to asses a single factor. Thus, the metric of the observed item $\left(y_{i}\right)$ is presumed equivalent to the one for the response variable $\left(y_{i}{ }^{*}\right)$ underlying it (Finney and DiStefano 2006). When items are categorical, this framework is modified to reflect this data characteristic by explicitly modeling the relationship between the latent factor $\left(\eta_{i}\right)$ and the response variable $\left(y_{i}^{*}\right)$ for each item. I explain this feature and its implications for interpretation of the estimates in the Results section.
} 


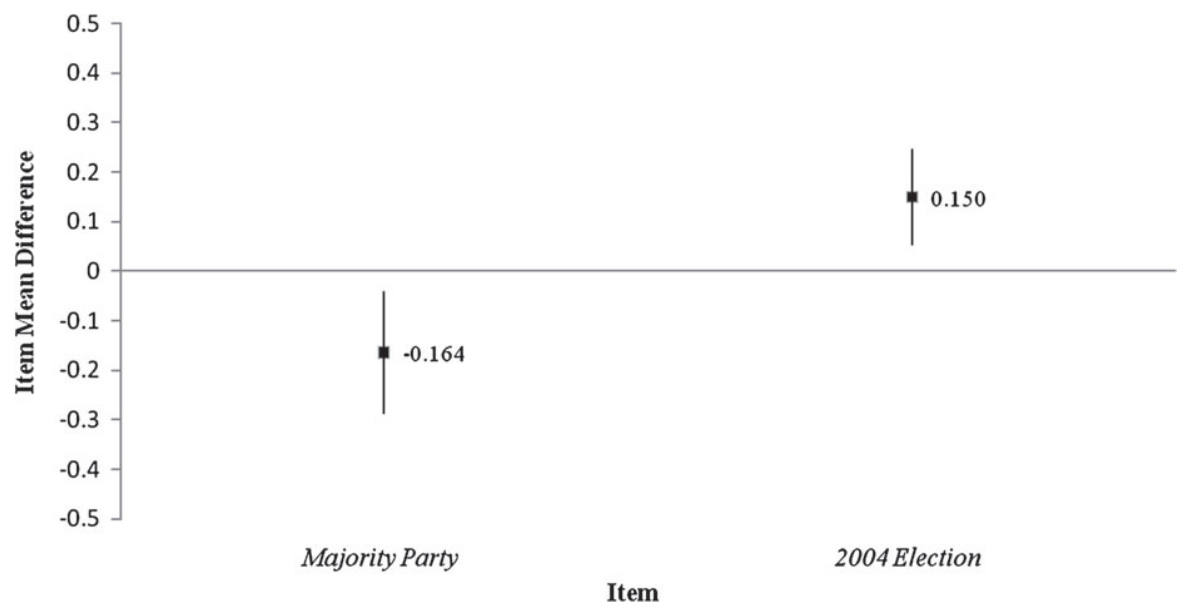

Fig. 3 Political knowledge: DIF estimates with $95 \%$ confidence intervals.

difference on a survey question. Because the emergence of DIF is akin to unequal item intercepts (e.g., Brown 2007), it suggests that English (Spanish) interviewees are systematically over- or under-reporting their political attitude through an affected item.

\section{Data}

My application of MIMIC models uses the LNS (Fraga et al. 2006). This English/Spanish telephone survey ran from November 17, 2005 through August 4, 2006 and yielded 8634 completed interviews of selfidentified Latino residents of the United States. I utilize data for the five largest national origin groups in the survey: Cubans, Dominicans, Mexicans, Puerto Ricans, and Salvadorans, for a total $N=7688$. This permits me to create several distinct groups with a large number of cases, thus ensuring sufficient statistical power to reliably detect the influence of national origin on the attitudes under investigation. ${ }^{8}$

I estimate a MIMIC model for four (4) latent constructs in the LNS: (1) perceptions of Americanism; (2) political knowledge; (3) Latino attachment; and (4) perceived intergroup competition. ${ }^{9}$ The items for these constructs and their English/Spanish translations are in Appendix 1. For perceptions of Americanism, the item battery read: "When you think of what it means to be fully American in the eyes of most Americans, do you think it is very important, somewhat important, or not important to: ..." Respondents then rated how important it is "to have been born in the U.S." and "to be Christian," among other characteristics. ${ }^{10}$

\footnotetext{
$\overline{{ }^{8} \text { The smallest national }}$ origin group in the pending analysis is Dominicans $(n=335)$. While small, this group of cases still permits a meaningful analysis. The next smallest group excluded from the analysis is Guatemalans $(n=149)$. Here, if I were to include this group and find significant effects, I would be hard pressed to say whether the influence stems from having a Guatemalan national origin or whether the effect captures something unique about those Guatemalans in this survey. For this reason, I concentrate on the five groups described above.

${ }^{9}$ In the interest of space, I define each construct here and refer readers to pertinent literature. These citations are exemplary, but by no means exhaustive. Perceptions of Americanism refer to Latinos' sense that national identity is ethno-racially delimited (e.g., Higham 1981; King 2000). Put differently, this construct captures the degree to which an individual sees the boundaries of national identity as ethno-racially impermeable. Thus, the more intense these perceptions, the less relevant American identity should be for one's political behavior. On American identity and Latinos, see Fraga et al. (2010) and Citrin et al. (2007). On identity permeability, see Jackson et al. (1996) and Lalonde and Silverman (1994). Political knowledge refers to individuals' factual information about politics (Delli Carpini and Keeter 1996). Here, greater political knowledge, among other things, increases people's engagement with politics. On Latino political knowledge, see Abrajano (2010) and Abrajano and Alvarez (2010). Latino attachment refers to identification with other Latinos. Formally, it refers to one's identification with the social object, Latino (Tajfel 1981). A key component of group attachment is a sense of commonality with it (Turner et al. 1987; Garcia 2003; Garcia Bedolla 2005). It is theorized that the measures at hand capture this sense of attachment. Finally, perceived intergroup competition refers to one's sense of conflict, across several domains, with an outgroup relative to one's ingroup. Recently, this construct has been used to study Latino perceptions of political and economic competition with Blacks (McClain et al. 2006, 2011; Barreto et al. 2010, forthcoming). This construct is generally measured by subtracting one's perceptions of competition with Latinos from one's perceptions of competition with Blacks. Thus, I examine the items attending each set of perceptions.

${ }^{10}$ These items lack a "don't know" option. Krosnick (2002) shows that items like these do not necessarily force people with no attitude to construct one on the spot, as is often suspected. Nevertheless, if this item feature has deleterious effects, they should manifest themselves in poor attitude measurement. The results in Table 1 rule out this concern.
} 


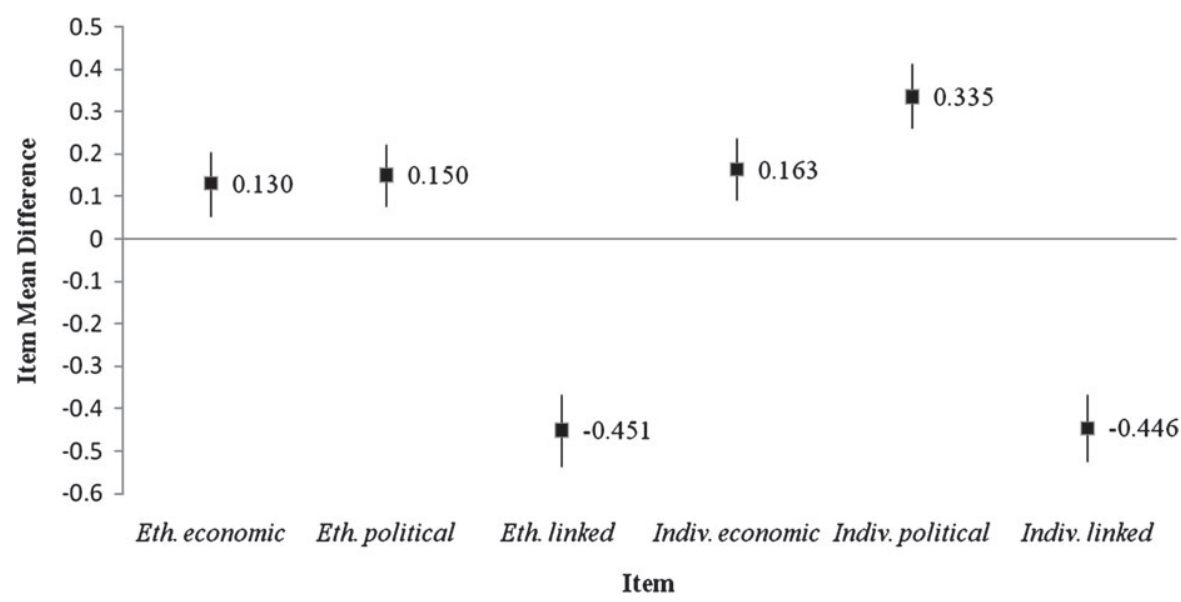

Fig. 4 Latino attachment: DIF estimates with $95 \%$ confidence intervals.

In turn, the items for political knowledge asked respondents to identify: (1) the majority political party in the House of Representatives? (2) who (Bush or Kerry) won more presidential votes in one's state during the ' 04 election? and (3) the more conservative party at the national level? Next, the items for Latino attachment gauged, inter alia, respondent perceptions about political and economic commonality with other Latinos. ${ }^{11}$ Finally, items for perceptions of intergroup competition gauged one's sense of political and economic competition with African-Americans and Latinos, respectively. ${ }^{12}$

In addition, several covariates are utilized in the regression component of each MIMIC model. Primary among these is Language, a dummy variable indicating the language of interview, where Spanish is the omitted category. Each model also includes covariates gauging the social and political differences among Latinos that scholars find theoretically important, including generational status, national origin, citizenship status, education, partisanship, and access to political information (Garcia Bedolla 2005; Branton 2007; Abrajano 2010; Abrajano and Alvarez 2010). Generational status is gauged by dummy variables for second generation and third generation, with the first generation as the omitted category. ${ }^{13}$ National origin is assessed through dummy variables for Cuban, Puerto Rican, Dominican, and Salvadoran, with Mexicans as the baseline category. Education is a continuous variable ranging from 0 (no education) to 7 (graduate or professional degree). Partisanship is captured through the binary variables Democrat, Republican, Independent, and Don't Care, with those reporting "don't know" as the reference category. ${ }^{14}$ Citizen gauges whether respondents are naturalized citizens, with unnaturalized respondents as the omitted category. English media and Spanish media indicate the language of television, radio, and newspapers used for public affairs information. Those reporting equal use of English and Spanish media are the omitted category. Finally, Switch captures respondents who switch their language of interview during the survey (Poplack 1982; Garcia 2010), with those using the same language throughout the survey as the reference group.

\section{Results}

I begin by using a Confirmatory Factor Analysis (CFA) to validate the items measuring each latent attitude. Here, we are looking for evidence of well-fitting measurement models for each construct, as indicated by a CFI and TLI above 0.90, an RMSEA below 0.10, and an absence of large residuals. These thresholds are typically recommended by researchers to assess model fit (Browne and Cudeck 1993; Brown 2007). I generally find evidence of well-fitting measurement models. For instance, the CFA for perceptions of Americanism (Table 1 ) meets or surpasses the thresholds set above $(\mathrm{CFI}=0.993$; $\mathrm{TLI}=0.958$; $\mathrm{RMSEA}=$

\footnotetext{
${ }^{11}$ The word attachment is synonymous with identity, especially in work employing social identity theory (e.g., Huddy and Khatib 2007), which I utilize in subsequent analyses. I use both terms interchangeably.

${ }^{12}$ These items also did not contain a "don't know" option.

${ }^{13}$ First-generation respondents are individuals who are foreign born. Second-generation individuals are native born with foreign-born parents. Third-generation individuals are native born with native-born parents.

14"Don't knows" are included as the reference category in order to minimize the number of missing observations.
} 


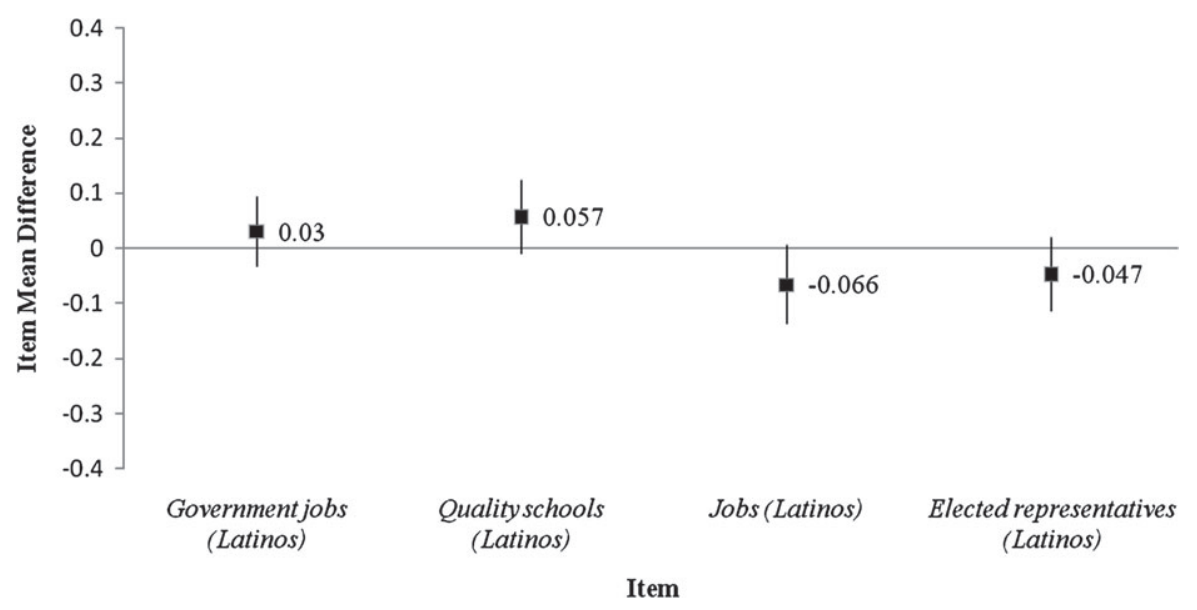

Fig. 5 Perceptions of intergroup competition (Latinos): DIF estimates with 95\% confidence intervals.

0.043). A similar pattern is displayed by the CFAs for political knowledge (Table 2: CFI $=1.00 ;$ TLI $=$ 1.00; RMSEA $=0.00),{ }^{15}$ Latino attachment (Table 3: CFI $\left.=0.981 ; \mathrm{TLI}=0.953 ; \mathrm{RMSEA}=0.072\right)$, and perceptions of intergroup competition (Table 4: CFI $=0.988$; $\mathrm{TLI}=0.982$; $\mathrm{RMSEA}=0.058$ ).

Each CFA also yields meaningful estimates. Because these CFAs utilize categorical items, the interpretation of the loadings differs from CFAs where items are continuous (Brown 2007). In a CFA with categorical items, each indicator is assumed to reflect a unique latent response variable $\left(y^{*}\right)$ that is continuous and normally distributed (Finney and DiStefano 2006). This implies that each observed indicator is a coarse and imperfect gauge of its underlying response variable. ${ }^{16}$ Within this framework, the variances of each $y^{*}$ along with the latent factor are standardized to 1.0. Hence, the factor loadings attending each item reveal the change in each item's $y^{*}$, given a SD shift in the latent factor. Thus, in the current analysis of perceptions of Americanism (Table 1), a SD shift in this latent factor produces a 0.763 shift in the response variable underlying Born in the U.S., which is a strong effect.

Similarly, substantive effects are yielded for items attending other constructs. For instance, a SD unit increase in latent political knowledge (Table 2) produces a 0.790 and 0.706 SD change, respectively, in the response variables underlying Majority party and Conservative party. A SD change in latent Latino attachment (Table 3) leads to a 0.616 and 0.606 SD shift in the response variables underlying

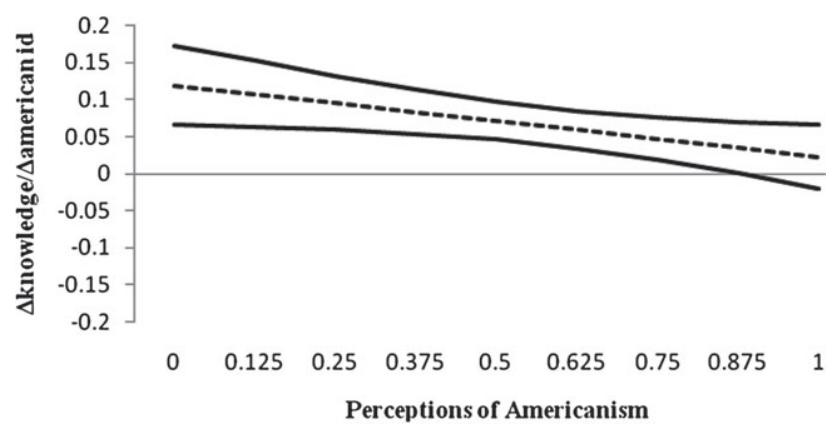

Fig. 6 Marginal effect of American ID (pooled) with 95\% confidence intervals.

\footnotetext{
${ }^{15}$ This model is just identified, which means that the model will display perfect fit since there are just enough variances/covariances to estimate the number of model parameters. These model estimates, however, can still be assessed for their magnitude and meaningfulness (Brown 2007). Moreover, I cross checked these estimates with those from an over-identified model, which increased the number of variances/covariances available for estimation through a two-factor model involving perceptions of Americanism and political knowledge. In that analysis, the loadings for the items tapping political knowledge are virtually identical to those reported in Table 2. Specifically, majority party $=0.791$; conservative party $=0.706$; and election $2004=0.594$.

${ }^{16}$ In contrast, when data are continuous and normally distributed, the metric of an observed indicator is assumed equivalent to its attendant response variable (see Finney and DiStefano 2006).
} 
Table 9 Levels of political knowledge as a function of national and Latino attachment

\begin{tabular}{lccc}
\hline & Pooled & English interviewees & Spanish interviewees \\
\hline National attachment & $0.12^{*}(0.03)$ & $0.09(0.05)$ & $0.10^{*}(0.04)$ \\
Latino attachment & $-0.05(0.05)$ & $-0.05(0.07)$ & $-0.01(0.06)$ \\
Perceptions of Americanism & $-0.01(0.06)$ & $-0.03(0.11)$ & $-0.004(0.07)$ \\
National attachment $\times$ Americanism & $-0.10^{*}(0.04)$ & $-0.04(0.09)$ & $-0.06(0.05)$ \\
Latino attachment $\times$ Americanism & $0.15^{*}(0.07)$ & $0.10(0.12)$ & $0.14(0.10)$ \\
Adjusted $R^{2}$ & 0.30 & 0.25 & 0.19 \\
$N$ & 7401 & 2925 & 4476 \\
\hline
\end{tabular}

Note. Cell entries are OLS coefficients with robust SEs in parentheses. Models also included the following covariates: partisanship, education, citizenship, generational status, national origin, and language of media. In addition to these covariates, the pooled model included language of interview. All variables in each model are rescaled to run from 0 to 1.

$* p<.05$, two-tailed test.

Ethnic-political commonality and Individual-economic commonality, respectively. Finally, latent perceptions of intergroup competition with Blacks (Table 4) generate a 0.864 and 0.820 SD shift in the response variables for Government jobs and Quality schools, respectively.

Given the preceding results, I regress each latent factor on the covariates described earlier. Here, the direct effects from language of interview to the items measuring each latent attitude-that is, the DIF estimates-are initially constrained to zero, which implies that language influences the level of one's attitude but not one's interpretation of the items measuring the attitude — an assumption typically made in applied work. Turning to the results for perceptions of Americanism (Table 5), I find that language affects this attitude despite extensive statistical controls for social and political heterogeneity among Latinos. Specifically, English interviewees register a mean that is 0.284 units lower than Spanish interviewees on latent perceptions of Americanism. This effect size is comparable in absolute terms to other covariates in the model, such as Democrat $(0.237, p<.01)$ and Republican $(0.242, p<.01)$, and stronger than the effect for education $(-0.082, p<$ $.01)$. Furthermore, second- $(0.255, p<.01)$ and third-generation $(0.228, p<.01)$ Latinos display heightened perceptions of Americanism compared to their first-generation counterparts.

Similar evidence is uncovered for the other latent constructs. English interviewees register a mean that is 0.174 units higher than Spanish interviewees on latent political knowledge (Table 6), an effect that is independent of one's media source and the strong effects of partisanship. Moreover, English interviewees register a mean level of Latino attachment that is 0.244 units lower than Spanish interviewees (Table 7), an effect outperforming second-generation $(0.050, n s)$ and third-generation $(-0.109, n s)$ status, education $(0.025$, $p<.012)$, and citizenship status $(0.095, p<.036)$. Finally, English interviewees display a level of perceptions of competition with Latinos that is 0.192 units lower than Spanish interviewees (Table 8), which compares favorably with other covariates, such as generational status. However, language only affects perceptions of competition with Latinos but not with Blacks. This suggests that language DIF perhaps affects only the items attending this construct in this two-factor model, a possibility that I further explore below.

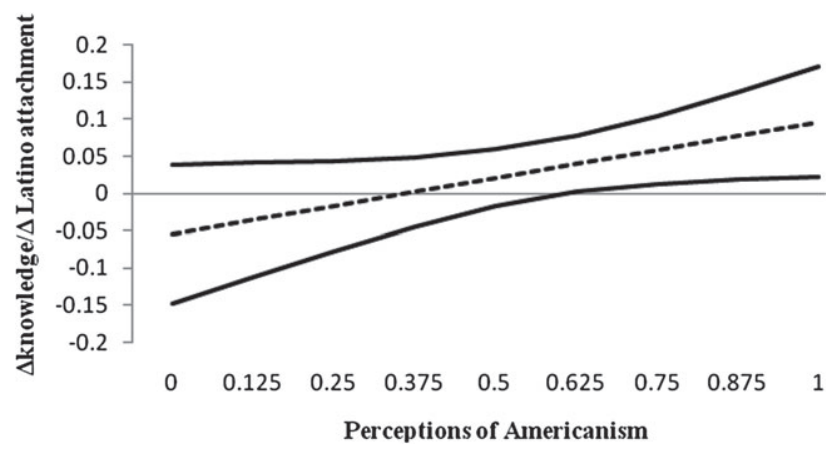

Fig. 7 Marginal effect of Latino attachment (pooled) with 95\% confidence intervals. 


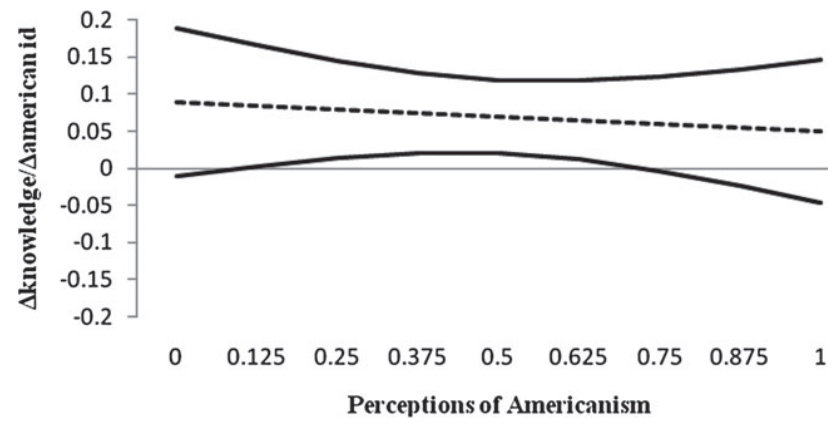

Fig. 8 Marginal effect of American ID (English) with 95\% confidence intervals.

Having accounted for heterogeneity in each latent variable, I assess the influence of language of interview on the interpretation of the items attending each construct. For each construct, I reestimate the regression models in Tables 5-8 and release the constraint on the path from language to each attendant indicator, one at a time (e.g., Mast and Lichtenberg 2000). A significant effect here implies DIF, that is, at any level of the latent attitude, English and Spanish interviewees score differently on an item.

These tests reveal that DIF affects more than half of the items under investigation. The DIF estimates are in standardized units. Thus, they are akin to Cohen's $d$, which reflects a mean difference between two groups, divided by the SD of both groups. Conventionally, $d$ values around $.20, .50$, and .80 are considered small, medium, and large, respectively (Brown 2007). Figures 2-5 display the DIF estimates for the items attending each construct under investigation. These figures reveal two main patterns. First, the affected items display language DIF ranging from small to medium amounts. ${ }^{17}$ Second, this linguistic bias displays an inconsistent direction across items within each affected construct. ${ }^{18}$ For instance, the analysis of Americanism perceptions (Fig. 2) shows English speakers score 0.218 units higher on Born in U.S., yet 0.384 units lower on Speak English. When focusing on political knowledge (Fig. 3), language of interview affects the meaning and interpretation of the items, Majority party $(-0.164, p<.01)$ and 2004 election $(0.150, p<.01)$. Similar findings emerge for Latino attachment (Fig. 4) where English interviewees score 0.130 points higher and 0.451 points lower on Ethnic economic and Ethnic linked fate, respectively. The one exception to this general pattern is latent perceptions of intergroup competition with Latinos (Fig. 5), which displays little evidence of DIF. ${ }^{19}$ The evidence thus suggests that language DIF can be a common feature of Latino survey items, even those for factual constructs like political knowledge. ${ }^{20,21}$

\footnotetext{
${ }^{17}$ The language differences found here are comparable in size to sex differences in latent traits, such as self-esteem, aggression, and academic skill (Eliot 2009). Similar to sex differences, I will show that even small to medium levels of language DIF can have important consequences for applied work.

${ }^{18}$ This pattern replicates and extends previous work (Pérez 2009).

${ }^{19}$ I restrict my focus here to perceptions of competition with Latinos because it was only there that language had a direct effect on this latent attitude. However, the absence of DIF also extends to perceived competition with Blacks, where language was unassociated with this latent attitude. Either way, this is a key finding because it shows that not all items in multilingual surveys will be affected by language DIF. The challenge for subsequent research is to determine when and why language DIF emerges.

${ }^{20}$ It can be reasonably argued that including partisanship in these MIMIC models is methodologically incorrect because the meaning of partisan labels differs between foreign born, Spanish-speaking Latinos and native born, English-speaking Latinos largely because the former have been primarily politically socialized outside the U.S. (Alvarez and Garcia Bedolla 2003; Abrajano 2010; Alvarez and Abrajano 2010). In support of this view, Hajnal and Lee $(2006,2011)$ find an uneven correspondence between one's partisanship and one's ideological orientation among Latinos. Given these insights, I reestimated the regression component of each MIMIC model without partisanship as a covariate and generated new DIF estimates. Critically, these new DIF estimates fall within the confidence intervals for the original DIF estimates produced via the models with partisanship as a covariate. Thus, DIF emerges irrespective of whether partisanship is included as a covariate (see Appendix2, Table A).

${ }^{21}$ These language DIF estimates are robust to other DIF sources. Extant research suggests generational status, national origin, and education as possible DIF sources (e.g., Branton 2007; Alvarez and Abrajano 2010). My analysis reveals that one item from the Americanism battery, Born in the U.S., was significantly affected by DIF arising from being Puerto Rican (-0.64), second generation (0.36), and third generation (0.40). Accounting for these sources of DIF does not significantly diminish the original language DIF estimate for this item (0.218 versus 0.200$)$.
} 


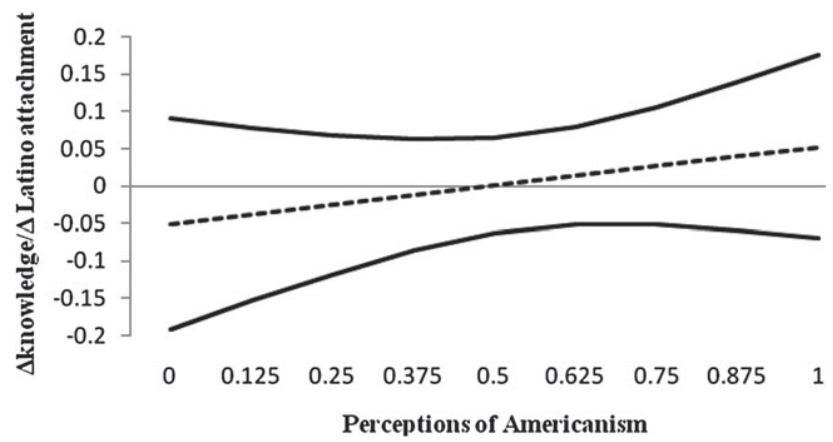

Fig. 9 Marginal effect of Latino attachment (English) with 95\% confidence intervals.

\section{The Consequences of Language DIF in Applied Survey Work}

I now demonstrate that using data affected by language DIF can yield misleading inferences about hypothesized relationships between variables. I test two hypothesized relationships between national identity, Latino attachment, and levels of political knowledge. Scholarship drawing on social identity theory (SIT) finds national identity boosts attention to and knowledge about politics (Huddy and Khatib 2007). This relationship follows from SIT's prediction that identifying with a group (e.g., the nation) predisposes one toward behaviors that involve one's group (e.g., learning about its politics). However, though Latinos robustly identify with the U.S. (de la Garza et al. 1996; Citrin et al. 2007; Fraga et al. 2010), it is plausible that the positive effect of national identity on political knowledge is undercut by whether Latinos believe this identity is ethno-racially exclusive. If a Latino senses American identity is ethno-racially impermeable (Lalonde and Silverman 1994; Jackson et al. 1996), this attachment should be less relevant for his/her political behavior. Thus, the link between national identity and political knowledge should weaken as this sense of identity impermeability intensifies. Moreover, a greater sense that American identity is impermeable should increase the salience of one's Latino identity. This should produce a positive association between Latino identity and political knowledge.

Accordingly, I estimate a model predicting political knowledge as a function of one's American identity, ${ }^{22}$ Latino identity, one's perceptions of Americanism, and the interaction between these variables, plus several key statistical controls. ${ }^{23}$ If the above hypotheses are correct, we should observe an increasingly negative relationship between American identity and political knowledge as perceptions of Americanism (i.e., identity impermeability) heighten. At the same time, we should observe an increasingly positive relationship between Latino identity and political knowledge as these perceptions of Americanism grow. Table 9 below reports the results of this analysis. ${ }^{24}$

Under the column labeled "pooled," we see evidence confirming these hypotheses. When perceptions of Americanism are at their minimum (0), national identity has a positive and statistically significant association with levels of political knowledge. In this condition, going from the lowest (0) to highest (1) level of American identity produces a shift of roughly one-tenth the range of the dependent variable. However, the interaction between American identity and perceptions of Americanism is significant and negative, which means perceptions of Americanism attenuate this relationship between national identity and political knowledge. In contrast, when perceptions of Americanism are at their minimum (0), Latino identity is unrelated to one's political knowledge. But as these perceptions intensify, Latino identity is

\footnotetext{
${ }^{22}$ American identity is measured with a single item, which reads: "[In general], how strongly do you think of yourself as American? 1) not at all; 2) not very strongly; 3) somewhat strongly; and 4) very strongly." This item is similar to ones previously used to measure national identity (Huddy and Khatib 2007).

${ }^{23}$ These covariates include language of interview, education, citizenship status, generational status, national origin, partisanship, and language of media. See data section of text for the operationalization of these covariates.

${ }^{24}$ One may reasonably wonder whether perceptions of Americanism truly capture a sense of how ethno-racially impermeable national identity is. This is a theoretical commitment supported empirically by the data. First, as theorized, these items capture the same underlying variable (Table 1). Second, as I will show, the variable does operate as hypothesized.
} 


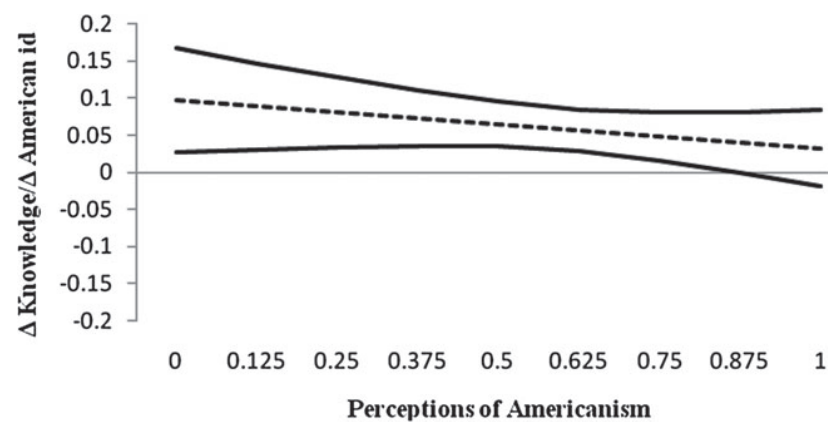

Fig. 10 Marginal effect of American ID (Spanish) with 95\% confidence intervals.

increasingly associated with greater levels of political knowledge. These interactive relationships are visually displayed in Figs. 6 and $7 .^{25}$

From this evidence, one might conclude that when Latino perceptions of Americanism are strong, political knowledge is negatively associated with American identity and positively related to Latino identity. Yet this inference is potentially misleading because it assumes that language DIF is absent from the items attending key variables in the model. We know that this assumption is untenable here, which means that we cannot meaningfully compare English and Spanish interviewees on these items. Thus, I disaggregate the data by language and rerun the previous analysis for English and Spanish interviewees separately (Reise et al. 1993). The last two columns from the left in Table 9 suggest that the previously uncovered relationships do not hold uniformly for English and Spanish interviewees. Figures 8-11 visually confirm this. Among English interviewees, national identity displays a patchy relationship with political knowledge across levels of perceptions of Americanism. Indeed, this relationship is statistically significant only in the middle range of perceptions of Americanism (Fig. 8). In turn, the relationship between Latino identity and political knowledge is wholly insignificant across the entire range of perceptions of Americanism among English interviewees (Fig. 9). In contrast, these relationships are more crisply estimated among Spanish interviewees. First, increased perceptions of Americanism attenuate the positive association between national identity and political knowledge (Fig. 10). Second, the highest levels of perceptions of Americanism produce a strong and positive relationship between Latino identity and political knowledge (Fig. 11). Thus, the originally hypothesized conditional relationships between national attachment, Latino identity, and perceptions of Americanism are more reliably estimated among Spanish interviewees when the data are disaggregated by language. ${ }^{26}$

\section{Discussion and Conclusions}

Using a MIMIC framework, I found that language of interview affected the construal of more than half of the survey items under analysis, thus leading Latino respondents to over- and under-report their true attitude within the same battery of items. Equally important, I showed that language DIF can lead one to reject a null hypothesis when it is true for some respondents. Nevertheless, it is important to clarify what these findings do not say about Latino survey items. These findings do not imply that Latino surveys fail to reliably capture Latino opinion. To make that claim, the CFAs for each latent attitude should have yielded poor-fitting models. Yet the opposite was true. Thus, the implication is not that bilingual survey items are shoddy. Rather, the evidence suggests that these items are measuring attitudes with different meanings for

\footnotetext{
${ }^{25}$ The dependent variable here is a 3 -item additive scale measuring latent political knowledge, which is theoretically continuous. For ease of interpretation and accessibility to a wider audience, this analysis utilizes OLS. Virtually identical results are obtained if one uses factor scores obtained from the CFA reported in Table 2.

${ }^{26}$ This general pattern emerges even if (1) one drops Born in the U.S. from perceptions of Americanism (see footnote 21) and (2) if one reruns these analyses in additive fashion, without perceptions of Americanism as a moderator. In both cases, the pattern found in the pooled data does not uniformly hold if one disaggregates the data by language. Moreover, it is unlikely that these differential patterns by language are due to insufficient power in the English or Spanish subsamples since each of these is large in absolute terms $(n>2,500$ for each language group).
} 


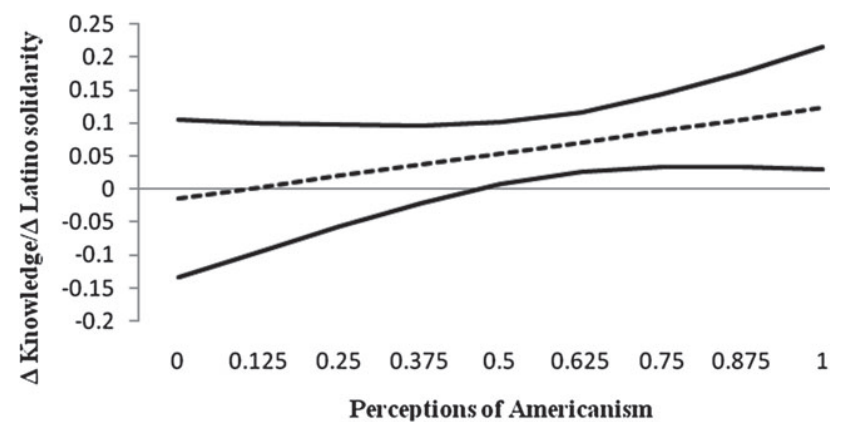

Fig. 11 Marginal effect of Latino attachment (Spanish) with 95\% confidence intervals.

each language group. This does not invalidate the study of Latino opinion, but it does caution against assuming the cross-language portability of survey items, thereby fortifying the view that language is a lens coloring one's political experiences and understanding (Lee 2001; Garcia Bedolla 2005; Pérez 2009).

MIMIC models require multiple items for an attitude of interest. If these data are available, it behooves researchers to verify (rather than assume) the absence of language DIF in multilingual surveys. Such an inquiry should involve the following concrete steps. First, scholars should have a theory about why a set of items measure an attitude. This will strengthen the link between conceptualization and the CFAs used to test the construct validity of items. ${ }^{27}$ Second, scholars should have a theory about why language might affect the items under study. For instance, in related work, I argue that language of interview primes one to think in a specific language throughout a survey. ${ }^{28}$ This priming mechanism means that we should generally find language DIF in survey items if there are linguistic differences in the nature of the attitudes being retrieved, an assumption supported by this paper. Third, given a well-fitting CFA, scholars must ensure that the regression component of the MIMIC model is well specified, so that observed differences between the groups being compared are statistically controlled. Here, extant work should guide one's choice of covariates. ${ }^{29}$ Of course, it is still possible for the groups under consideration to differ on some unobserved variable(s). To fully address this possibility, a different research design is required. In related work, for instance, I investigate this consideration using an experiment that randomizes the language of interview across bilingual respondents (Pérez 2011). Fourth, if language DIF is detected, scholars should disaggregate their observations by language to avoid uncovering artifactual associations between variables, as previously shown (Reise et al. 1993). ${ }^{30}$

Extant surveys go to great lengths to ensure variation in their pool of item translators. Yet biases still affect survey items. One solution, then, is richer socio-linguistic variation in item translators. Another solution is more extensive pretesting of translated items. Here, researchers might consider using focus groups and experiments. Focus groups often yield insights into the meaning of survey items and the cognitive processes underpinning individuals' responses (Hochschild 1981; Jones-Correa 1998; Waters 1999; Garcia Bedolla 2003; Jiménez 2009). Experiments can further tease out the implications of item wording for linguistic DIF by disentangling how language differences in item wording can influence the encoding, storage, and retrieval of political attitudes (Tourangeau et al. 2000). For instance, in related work, I study the consequences for item validity and reliability when there is a mismatch between individuals' reported proficiency and actual skill in the language of interview. ${ }^{31}$ Irrespective of approach, however, scholars will require a way to identify the sources of language effects in their data. While by no means a panacea, it is

\footnotetext{
${ }^{27}$ For the constructs analyzed here, see footnote 9.

${ }^{28}$ Pérez (2011).

${ }^{29}$ The aim here is to choose a parsimonious specification guided by theory rather than a "kitchen sink" approach.

${ }^{30}$ If DIF affects only some items, a pooled analysis can proceed using unaffected items while accepting a possible reduction in measurement reliability arising from using less items to asses an attitude(s) (e.g., Byrne et al. 1989).

${ }^{31}$ Pérez (2011). Experimentally, I randomly assign self-reported bilinguals to either (1) a control condition, where they choose the language of interview; (2) a condition where they are asked to complete the interview in English; and (3) a condition where respondents are asked to complete the interview in Spanish.
} 


\section{APPENDIX 1. English/Spanish Translations of Items}

\section{Perceptions of Americanism: English and Spanish Versions}

"When you think of what it means to be fully American in the eyes of most Americans, do you think it is very important, somewhat important, or not important to ..."

1. Have been born in the United States?

3 Very important

2 Somewhat important

1 Not important

2. To speak English well?

3 Very important

2 Somewhat important

1 Not important

3. To be White?

3 Very important

2 Somewhat important

1 Not important

4. To be Christian?

3 Very important

2 Somewhat important

1 Not important
"Cuando usted piensa en lo que significa ser completamente Americano(a) en los ojos de la mayoría de los Americanos, usted piensa que es muy importante, algo importante, o nada importante ..."

1. Haber nacido en los EE.UU.

3 Muy importante

2 Algo importante

1 No importante

2. Hablar bien en ingles

3 Muy importante

2 Algo importante

1 No importante

3. Ser blanco(a)

3 Muy importante

2 Algo importante

1 No importante

4. Ser Cristiano(a)

3 Muy importante

2 Algo importante

1 No importante

Political Knowledge: English and Spanish Versions

1. Which political party, Democrat or Republican, has a majority in the House of Representatives?

\section{Democrat \\ 2 Republican \\ $3 \mathrm{DK}$}

2. In the United States, presidential elections are decided state-by-state. Can you tell me, in the election of 2004, which candidate, Bush or Kerry, won the most votes in (respondent's current state of residence)?

1 Bush

2 Kerry

3 DK

4 NA/Refused

3. Which one of the political parties is more conservative than the other at the national level, Democrats or Republicans?

1 Democrats

2 Republicans

3 DK/Refused
1. ¿Qué partido político, Demócrata o Republicano, tiene la mayoría en la Cámara de Representantes de EE.UU.?
1 Demócrata
2 Republicano
3 NS

2. En los EE.UU., las elecciones presidenciales son decididas estado-por-estado. ¿Puede decirme, en las elecciones del 2004, qué candidato, Bush o Kerry, ganó la mayoría de votos en (el estado en donde vive hoy)?

1 Bush

2 Kerry

$3 \mathrm{NS}$

4 NA/Rehusa

3. Cuál de los partidos políticos es más conservador que el otro a nivel nacional, Demócrata o el Republicano?

1 Demócrata

2 Republicano

3 NS/Rehusa 
Latino Attachment: English and Spanish Versions

1. Thinking about issues like job opportunities, educational attainment, or income, how much do you have in common with other Latinos/Hispanics? Would you say you have a lot in common, some in common, little in common, or nothing at all in common?

4 Lot

3 Some

2 Little

1 Nothing

5 DK/NA

2. Now thinking about things like government services and employment, political power, and representation, how much do you have in common with other Latinos/ Hispanics? Would you say you have a lot in common, some in common, little in common, or nothing at all in common?

4 Lot

3 Some

2 Little

1 Nothing

5 DK/NA

3. How much does your "doing well" depend on other Latinos/Hispanics also doing well? A lot, some, a little, or not at all?

4 Lot

3 Some

2 Little

1 Nothing

5 DK/NA

4. Thinking about issues like job opportunities, educational attainment, or income, how much do [ethnic subgroup] have in common with other Latinos/Hispanics? Would you say [ethnic subgroup] have a lot in common, some in common, little in common, or nothing at all in common?

4 Lot

3 Some

2 Little

1 Nothing

5 DK/NA

5. Now thinking about things like government services and employment, political power, and representation, how much do [ethnic subgroup] have in common with other Latinos/Hispanics? Would you say [ethnic subgroup] have a lot in common, some in common, little in common, or nothing at all in common?

4 Lot

3 Some

2 Little

1 Nothing

5 DK/NA
1. Pensando en asuntos como oportunidades de trabajo, logros educacionales o ingreso monetario, cuanto tiene usted en común con otros latinos/hispanos? Diría que usted tiene mucho en común, algo en común, poco en común, o nada en común?
4 Mucho
3 Algo
2 Poco
1 Nada
5 NS/NA

2. Ahora, pensando en asuntos como servicios y empleos del gobierno, poder político, y representación, cuanto tiene usted en común con otros latinos/hispanos? Diría que usted tiene mucho en común, algo en común, poco en común, o nada en común?

4 Mucho

3 Algo

2 Poco

1 Nada

5 NS/NA

3. En qué medida depende que usted avance de que otros latinos/hispanos también avancen? Mucho, algo, poco, o nada?
4 Mucho
3 Algo
2 Poco
1 Nada
5 NS/NA

4. Pensando en asuntos como oportunidades de empleo, educación o ingreso, cuanto tiene $1: A Q B 4 C$ en común con otros latinos/ hispanos? Diría que $\backslash$ :AQB4C tiene mucho en común, algo en común, poco en común, o nada en común?

4 Mucho

3 Algo

2 Poco

$1 \mathrm{Nada}$

5 NS/NA

5. Ahora, pensando en asuntos como servicios y empleos del gobierno, poder político, y reprsentación, cuanto tiene $\mathrm{I}$ AQB4C en común con otros latinos/hispanos? Diría que ।:AQS4B tiene mucho en común, algo en común, poco en común, o nada en común?

4 Mucho

3 Algo

2 Poco

1 Nada

5 NS/NA 
6. How much does [ethnic subgroup] "doing well" depend on other Latinos/Hispanics also doing well? A lot, some, a little, or not at all?
4 Lot
3 Some
2 Little
1 Nothing
5 DK/NA

6. En qué medida depende que los [Respuesta a pregunta B4] avancen de que otros latinos/hispanos lo estén pasando bien? Mucho, algo, poco, o nada?
4 Mucho
3 Algo
2 Poco
1 Nada
5 NS/NA

Note: AQB4C refers to the ethnic subgroup reported by a respondent earlier in the survey through item B4.

Perceptions of intergroup competition: English and Spanish Versions

Some have suggested [Hispanics/Latinos] are in competition with African-Americans. After each of the next items, would you tell me if you believe there is strong competition, weak competition, or no competition at all with African-Americans? How about...

1. In getting jobs?

3 Strong competition

2 Weak competition

1 No competition

2. Having access to education and quality schools?

3 Strong competition

2 Weak competition

1 No competition

3. Getting jobs with the city or state government?

3 Strong competition

2 Weak competition

1 No competition

4. Having [Hispanic/Latino] representatives

in elected office?

3 Strong competition

2 Weak competition

1 No competition
Algunas personas han sugerido que los latinos o hispanos estan en competencia con Afro-Americanos. Despues que yo lea cada uno de los siguientes artículos, podria decirme si usted cree que existe una competencia fuerte, una competencia débil, o que no hay competencia con Afro-Americanos?

Que te parece...

1. En obtener trabajo?

3 Competencia fuerte

2 Competencia débil

1 No hay competencia

2. En el tener acceso a la educación y a escuelas de calidad?

3 Competencia fuerte

2 Competencia débil

1 No hay competencia

3. En obtener empleos con el gobierno de la ciudad o del estado?

3 Competencia fuerte

2 Competencia débil

1 No hay competencia

4. En el tener representantes latinos en oficinas obtenidas por voto?

3 Competencia fuerte

2 Competencia débil

1 No hay competencia 


\section{APPENDIX 2. Table A: DIF Estimates from Models Without Partisanship, With Original Confidence Intervals (CI)}

\begin{tabular}{lc}
\hline & New DIF, Original CI \\
\hline Born in U.S. & $0.221,(0.112,0.306)$ \\
Speak English & $-0.388,(-0.485,-0.283)$ \\
Being White & $0.195,(0.115,0.295)$ \\
Being Christian & $-0.150,(-0.239,-0.077)$ \\
Majority Party & $-0.160,(-0.287,-0.041)$ \\
2004 Election & $0.140,(0.053,0.245)$ \\
Ethnic_economic & $0.133,(0.063,0.215)$ \\
Ethnic_political & $0.150,(0.083,0.231)$ \\
Ethnic_linked fate & $-0.468,(-0.560,-0.394)$ \\
Individual-economic & $0.170,(0.098,0.246)$ \\
Individual-political & $0.353,(0.276,0.430)$ \\
Individual-linked fate & $-0.453,(-0.540,-0.380)$ \\
\hline
\end{tabular}

Note. The DIF estimates reported here were yielded through models that omitted partisanship as a covariate. The confidence intervals reported here are those from the DIF estimates reproduced in figures 2 through 4 . Those DIF estimates were yielded by models that included partisanship as a covariate (see tables 5 through 8 ).

hoped that scholars of language and politics will consider integrating MIMIC models into their diverse methodological toolkits.

\section{References}

Abrajano, Marisa A. 2010. Campaigning to the new American electorate. Palo Alto, CA: Stanford University Press.

Abrajano, Marisa A., and R. Michael Alvarez. 2010. New faces, new voices: The Hispanic electorate in America. Princeton, NJ: Princeton University Press.

Alvarez, R. Michael, and Lisa Garcia Bedolla. 2003. The foundations of Latino voter partisanship: Evidence from the 2000 elections. The Journal of Politics 65:31-49.

Barreto, Matt A., Ben Gonzalez, and Gabriel Sanchez. 2010. Rainbow coalition in the golden state? Exposing myths, uncovering new realities in Latino attitudes toward Blacks. In Black and brown Los Angeles: A contemporary reader, eds. L. Pulido and J. Kun, 1-36. Berkeley, CA: University of California Press.

Barreto, Matt A., Gabriel Sanchez, and Jason Morin. Forthcoming. Perceptions of competition between Latinos and Blacks: The development of a relative measure of inter-group competition. In Just neighbors? Research on African American and Latino Relations in the U.S., eds. E. Telles, G. Rivera-Salgado, and S. Zamora. New York: Russell Sage Foundation.

Benet-Martinez, Veronica, and Oliver P. John. 1998. Los Cinco Grandes across cultures and ethnic groups: Multitrait multimethod analyses of the Big Five in Spanish and English. Journal of Personality and Social Psychology 75:729-50.

Bollen, Kenneth A. 1989. Structural equations with latent variables. New York: Wiley.

Branton, Regina. 2007. Latino attitudes toward various areas of public policy: The importance of acculturation. Political Research Quarterly 60:293-303.

Brown, Timothy A. 2007. Confirmatory factor analysis for applied research. New York: Guilford Press.

Browne, Michael W., and Robert Cudeck. 1993. Alternative ways of assessing model fit. In Testing structural equation models, eds. Kenneth A. Bollen and J. Scott Long, 136-62. Newbury Park, CA: Sage Publications.

Byrne, Barbara M., and David Watkins. 2003. The Issue of Measurement Invariance Revisited. Journal of Cross-Cultural Psychology 34(2):155-175.

Byrne, Barbara M., Richard J. Shavelson, and Bengt Muthén. 1989. Testing for the equivalence of factor covariance and mean structures: The issue of partial measurement invariance. Psychological Bulletin 105:456-466.

Citrin, Jack, Amy Lerman, Michael Murakami, and Kathryn Pearson. 2007. Testing Huntington: Is Hispanic immigration a threat to American identity? Perspectives on Politics 5:31-48.

Davidov, Eldad. 2009. Measurement equivalence of nationalism and constructive patriotism in the ISSP: 34 countries in a comparative perspective. Political Analysis 17:64-82.

de la Garza, Rodolfo O., Angelo Falcon, and F. Chris Garcia. 1996. Will the Real Americans Please Stand Up: Anglo and MexicanAmerican Support of Core American Political Values. American Journal of Political Science 40(2):335-351.

de la Garza, Rodolfo O., Louis DeSipio, F. Chris Garcia, John Garcia, and Angelo Falcon. 1992. Latino voices: Mexican, Puerto Rican, and Cuban perspectives on American politics. Boulder, CO: Westview Press.

Delli Carpini, Michael X., and Scott Keeter. 1996. What Americans know about politics and why it matters. New Haven, CT: Yale University Press.

Diaz-Morales, Juan Francisco, Joseph R. Ferrari, Karem Diaz, and Doris Argumedo. 2006. Factorial structure of three procrastination scales with a Spanish adult population. European Journal of Psychological Assessment 22:132-37. 
Eliot, Lise. 2009. Pink brain, blue brain: How small differences grow into troublesome gaps-and what we can do about them. Boston, MA: Houghton Mifflin Harcourt.

Elkins, Zachary, and John Sides. 2010. The vodka is potent, but the meat is rotten: Evaluating measurement equivalence across contexts. Unpublished manuscript.

Finney, Sara J., and Christine DiStefano. 2006. Non-normal and categorical data in structural equation modeling. In Structural equation modeling: A second course, eds. G. R. Hancock and R. O. Mueller, 269-314. Madison, WI: Information Age Publishing.

Fraga, Luis R., John A. Garcia, Rodney Hero, Michael Jones-Correa, Valerie Martinez-Ebers, and Gary M. Segura. 2006. Latino National Survey (LNS). Ann Arbor, MI: Inter-University Consortium for Social and Political Research.

Fraga, Luis Ricardo, John A. Garcia, Rodney E. Hero, Michael Jones-Correa, Valerie Martinez-Ebers, and Gary M. Segura. 2010. Latino lives in America: Making it home. Philadelphia, PA: Temple University Press.

Gallo, Joseph J., James C. Anthony, and Bengt O. Muthén. 1994. Age Differences in the Symptoms of Depression: A Latent Trait Analysis. Journal of Gerontology: Psychological Sciences 49: P251-P264.

Garcia, John A. 2003. Latino politics in America: Community, culture, and interests. Lanham, MD: Rowman \& Littlefield Publishers, Inc.

- 2010. Language of interview: Exploring the effects of changing languages during the LNS interview. Unpublished manuscript.

Garcia Bedolla, Lisa 2003. The identity paradox: Latino language, politics, and selective dissociation. Latino Studies 1:264-83.

2005. Fluid borders: Latino power, identity, and politics in Los Angeles. Berkeley, CA: University of California Press. 2009. Latino politics. Malden, MA: Polity Press.

Hajnal, Zoltan, and Taeku Lee. 2006. Out of line: Immigration and party identification among Latinos and Asian Americans. In Transforming politics, transforming America: The political and civic incorporation of immigrants in the United States, eds. T. Lee, S. K. Ramakrishnan, and R. Ramírez, 129-50. Charlottesville, VA: University of Virginia Press.

Hajnal, Zoltan L., and Taeku Lee. 2011. Why Americans don't join the party: Race, immigration, and the failure (of political parties) to engage the electorate. Princeton, NJ: Princeton University Press.

Hambleton, Ronald K., H. Swaminathan, and H. Jane Rogers. 1991. Fundamentals of item response theory. Newbury Park, CA: Sage Publications.

Higham, John. 1981. Strangers in the land: Patterns of American nativism, 1860-1925. New York: Atheneum.

Hochschild, Jennifer L. 1981. What's fair: American beliefs about distributive justice. Cambridge: Harvard University Press.

Huddy, Leonie, and Nadia Khatib. 2007. American patriotism, national identity, and political involvement. American Journal of Political Science 51:63-77.

Jackson, Linda A., Linda A. Sullivan, Richard Harnish, and Carole N. Hodge. 1996. Achieving positive social identity: Social mobility, social creativity, and permeability of group boundaries. Journal of Personality and Social Psychology 70:241-254.

Jiménez, Tomás. 2009. Replenished ethnicity: Mexican Americans, immigration, and identity. Berkeley, CA: University of California Press.

Jones-Correa, Michael. 1998. Between two nations: The political predicament of Latinos in New York City. Ithaca, NY: Cornell University Press.

Jöreskog, Karl G., and Arthur S. Goldberger. 1975. Estimation of a model with multiple indicators and multiple causes of a single latent variable. Journal of the American Statistical Association 70:631-39.

King, Desmond. 2000. Making Americans: Immigration, race, and the origins of the diverse democracy. Cambridge: Harvard University Press.

Kirkman-Liff, Bradford, and Delfi Mondragón. 1991. Language of interview: Relevance for research of southwest Hispanics. American Journal of Public Health 81:1399-404.

Krosnick, Jon A. 2002. The causes of no-opinion responses to attitude measures in surveys: They are rarely what they appear to be. In Survey nonresponse, eds. R. M. Groves, D. A. Dillman, J. L. Eltinge, and R. J. A. Little, 88-100. New York: Wiley.

Lalonde, Richard N., and Randy A. Silverman. 1994. Behavioral preferences in response to social injustice: The effects of group permeability and social identity salience. Journal of Personality and Social Psychology 66:78-85.

Lee, Sunghee, Hoang Anh Nguyen, May Jawad, and John Kurata. 2008. Linguistic minorities in a Health Survey. Public Opinion Quarterly 72:470-86.

Lee, Taeku. 2001. Language of interview effects and Latino mass opinion. Paper presented at the Annual Meeting of the Midwest Political Science Association, Chicago, IL.

Marín, Gerardo, and Barbara VanOss Marín. 1991. Research with Hispanic populations. Newbury Park, CA: Sage Publications.

Mast, Benjamin T., and Peter A. Lichtenberg. 2000. Assessment of functional abilities among geriatric patients: A MIMIC model of the functional independence measure. Rehabilitation Psychology 45:49-64.

McClain, Paula D., Niambi M. Carter, Victoria M. DeFrancesco Soto, Monique L. Lyle, Jeffrey D. Grynaviski, Shayla C. Nunnally, Thomas J. Scotto, J. Alan Kendrick, Gerald F. Lackey, and Kendra Davenport Cotton. 2006. Racial distancing in a Southern City: Latino immigrants views' of Black Americans. The Journal of Politics 68:571-84.

McClain, Paula D., Gerald F. Lackey, Efrén O. Pérez, Niambi M. Carter, Jessica Johnson Carew, Eugene Walton Jr., Candis S. Watts, Monique L. Lyle, and Shayla C. Nunnally. 2011. Intergroup relations in three southern cities: Black and White Americans' and Latino immigrants' attitudes. In Just neighbors? Research on African Americans and Latino relations in the United States, eds. E. Telles, G. Rivera-Salgado, and S. Zamora. New York: Russell Sage Foundation.

Muthén, Bengt. 1989. Latent variable modeling in heterogeneous populations. Psychometrika 54:557-85.

Pérez, Efrén O. 2009. Lost in translation? Item validity in bilingual political surveys. The Journal of Politics 71:1530-548.

. 2011. Speaking in tongues: Language, identity, and the nature of Latino politics. Unpublished manuscript, Vanderbilt UniversityTypescript. 
Perreira, Krista M., Natalia Deeb-Sossa, Kathleen Mullan Harris, and Kenneth Bollen. 2005. What are we measuring? An evaluation of the CES-D across race/ethnicity and immigrant generation. Social Forces 83:1567-602.

Poplack, Shana. 1982. Sometimes I'll start a sentence in Spanish y termino en español: Toward a typology of code-switching. In Spanish in the United States: Sociolinguistic aspects, eds. Jon Amastae and Luciacutea Elías-Olivares. New York, NY: Cambridge University Press.

Proitsi, P., G. Hamilton, M. Tsolaki, M. Lupton, M. Daniilidou, P. Hollingworth, N. Archer, C. Foy, F. Styilios, B. McGuinness, S. Todd, B. Lawor, M. M. Gill, C. Brayne, D. C. Rubinsztein, M. Owen, J. Williams, D. Craig, P. Passmore, S. Lovestone, and J. F. Powell. 2011. A Multiple Indicators Multiple Causes (MIMIC) model of Behavioural and Psychological Symptoms in Dementia (BPSD). Neurobiology of Aging 32:434-42.

Reise, Steven P., Keith F. Widaman, and Robin H. Pugh. 1993. Confirmatory factor analysis and item response theory: Two approaches for exploring measurement invariance. Psychological Bulletin 114:552-66.

Tajfel, Henri. 1981. Human groups and social categories. Cambridge: Cambridge University Press.

Tourangeau, Robert, Lance J. Rips, and Kenneth Rasinski. 2000. The psychology of survey response. Cambridge: Cambridge University Press.

Turner, John C., Michael A. Hogg, Penelope J. Oakes, Stephen D. Reicher, and Margaret S. Wetherell. 1987. Re-discovering the social group: A self-categorization theory. Oxford: Basil Blackwell.

Uhlaner, Carole J., and F. Chris Garcia. 2002. Latino public opinion. In Understanding public opinion, eds. B. Norrander and C. Wilcox, 77-102. Washington, DC: CQ Press.

Waters, Marcy C. 1999. Black identities: West Indian immigrant dreams and American realities. Cambridge, MA: Harvard University Press.

Welch, Susan, John Comer, and Michael Steinman. 1973. Interviewing in a Mexican-American community: An investigation of some potential sources of response bias. Public Opinion Quarterly 37:115-26. 